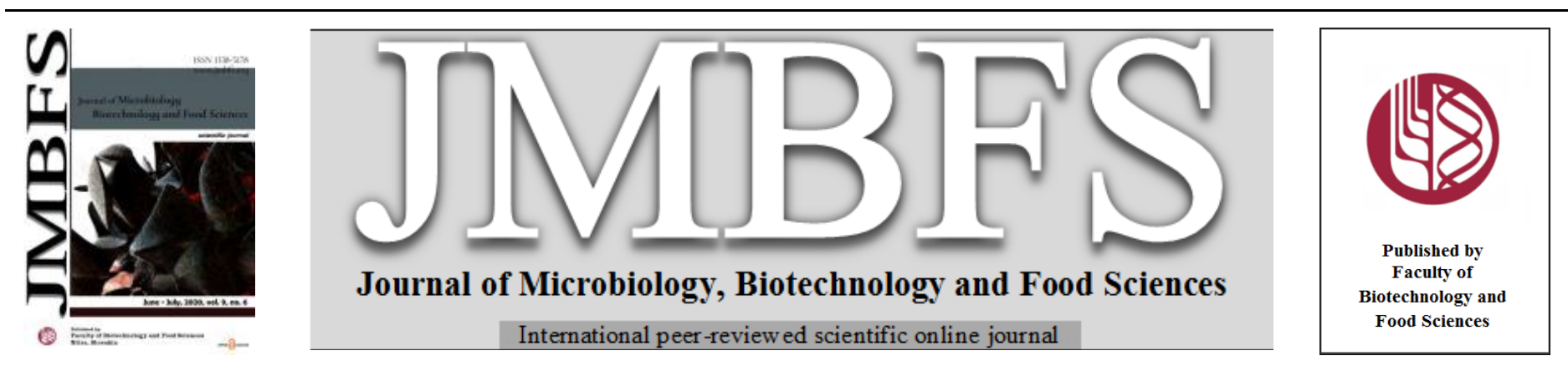

\title{
DETERMINATION OF THE VOLATILE COMPOSITION OF DISTILLATES WITH ADDED EXTRACTS OF HIPERICUM PERFORATYM L
}

\author{
Dimitar Dimitrov $^{l^{*}}$, Albena Parjanova ${ }^{2}$, Snezhana Ivanova ${ }^{2}$, Vanyo Haygarov ${ }^{1}$ \\ Address(es): \\ ${ }^{1}$ Department of Selection, Enology and Chemistry, Institute of Viticulture and Enology, 1 Kala Tepe str., 5800, Pleven, Bulgaria, phone number: +359885540245 \\ ${ }^{2}$ Department of Nutrition and Tourism, University of Food Technologies, 26 Maritza blvd., 4000, Plovdiv, Bulgaria
}

*Corresponding author: dimitar_robertov@abv.bg

doi: 10.15414/jmbfs.2020.9.6.1068-1072

\section{ARTICLE INFO}

Received 30. 9. 2019

Revised 10. 1. 2020

Accepted 10. 1.2020

Published 1. 6. 2020

Regular article

OPEN $\partial_{\text {AcCESS }}$

\begin{abstract}
A study for determination of the volatile composition of distillates with the addition of 50\% and 70\% ethanol extracts of St. John's wort (Hypericum perforatym $\mathrm{L}$ ) was conducted. The extracts were added in amounts of 20, 80, 100, 200, 400 and $600 \mathrm{ml}$. The remaining amount to liter was pure distillate obtained from the grapes of the variety "Melnik-55". Gas chromatographic (GC-FID) analysis for identification and quantification of the volatile components in the distillates obtained was performed. Various compounds from the groups of esters, higher alcohols, aldehydes and terpene alcohols have been identified. The methanol levels were found to be highest in the control sample $\left(364.74 \pm 0.32 \mathrm{mg} / \mathrm{dm}^{3}\right)$ and proportionally decreased with increasing of the fraction of added extract in the experimental variants. This contributed to obtained of the alcoholic distillate with decreased methanol content. A similar decrease in the amounts of acetaldehyde and ethyl acetate was observed. This reduced the harmful aromatic nuances that these compounds impart when they were in higher amounts. Four major higher alcohols have been identified - 3-methyl-1-butanol, 2-methyl-1-butanol, 2-butanol and 1-propanol. The ester composition was diverse, quantitatively dominated by the presence of ethyl acetate. A higher total terpene content was detected in the samples with the addition of Hypericum perforatym $\mathrm{L}$ extract compared to the control. This indicated increased final concentrations in the distillates (a consequence of the terpene composition of the herb), which may intensify its biological effect. The produced distillates with added extracts of Hypericum perforatym L can be used for obtaining of new higher alcoholic beverages with added medicinal herb extracts.
\end{abstract}

Keywords: St. John's wort (Hypericum perforatym L), distillate, esters, higher alcohols, aldehydes, methanol, terpenes, extract, grapes

\section{INTRODUCTION}

Modern focus in the work of various scientific groups is the search for solutions to improve the quality and health characteristics of foods by adding different plant extracts (with high biological activities) in them (Ivanov et al., 2014; Petkova et al., 2014; Stoilova et al., 2007).

St. John's wort (Hypericum perforatym L) is a plant of the Hypericaceae family. It is distributed throughout the all area of Bulgaria. The interest to the plant is mainly due to its rich chemical composition, with high content of biologically active compounds: hypericin, pseudohypericin, anthraquinone glycosides, flavone glycosides (hyperoside, rutin, quercetin), terpenes, sesquiterpenes, saponins, pectins, catechins, choline, and others (Landzhev, 2005). This rich chemical composition with high biological value makes promising to use the herb for incorporation into various food matrices.

The distillates are products derived from fermentation and subsequent distillation of grape pulp, fruit pulp, juices, by-products from wine-making (Marinov, 2005; Kostik et al., 2014).

The main groups of compounds forming the volatile content and aromatic matrix of distilled beverages are esters, aldehydes, higher alcohols and terpenes (in particular terpenic alcohols) (Velkov, 1996; Kostik et al., 2014).

The esters have the most significant aromatic influence. This is due to their low threshold of aromatic perception and their diverse aromatic nuances (Marku et al., 2015; Greizersten, 1981). They are accumulated in the beverage on the basis of two mechanisms: direct formation through yeast metabolism and chemical transformation - esterification - the process of bonding of alcohols with acids (Chobanova, 2012). According to Velkov (1996), the total ester content of grape distillates from unpressed wine marc ranges from $500.00-700.00 \mathrm{mg} / \mathrm{dm}^{3}$. Using pressed wine marc, the amount increases and can reach $840.00 \mathrm{mg} / \mathrm{dm}^{3}$. The dominant ester is ethyl acetate, which according to the author is in the range of $420.00-700.00 \mathrm{mg} / \mathrm{dm}^{3}$.

The aldehydes are another group of compounds that have a significant effect on the aromatic matrix of distillates. Acetaldehyde is dominant in this group
(Coldea et al., 2012; Tesevic et al., 2009). According to Velkov (1996), its concentration in grape distillates produced from unpressed wine marc ranges from $50.00-300.00 \mathrm{mg} / \mathrm{dm}^{3}$, and when used pressed wine marc it can reach $320.00 \mathrm{mg} / \mathrm{dm}^{3}$. The total amount of aldehydes in grape distillates ranges from $55.00-390.00 \mathrm{mg} / \mathrm{dm}^{3}$ (Velkov, 1996).

The higher alcohols are products of yeast amino acid metabolism (Tesevic et al. 2009; Kostik et al., 2014). They may also be the result of bacterial vital activity (Yankov et al., 2000). The main representatives of this group in the grape distillates are isoamylol, isobutanol and n-propanol, with the total content of higher alcohols ranging from $1400.00-2010.00 \mathrm{mg} / \mathrm{dm}^{3}$ (Velkov, 1996). The main importance is their role as a precursors to the esterification process in which they interact with acids to form esters with significant aromatic influence (Chobanova, 2012; Yankov et al., 2000).

Another group of compounds involved in the volatile composition and aromatic matrix of distillates are terpenes. They are not products of the fermentation process, but are metabolites of the vine plant. From it they pass directly to the distillate. Quantitatively dominant in this group are terpene alcohols linalool, geraniol, $\alpha$-terpineol, nerol and $\beta$-citronellol (Lengyel, 2012). They are responsible for the fruity aromatic nuances, which is especially important when fermenting grapes from muscat grapevine varieties (Luan et al., 2006).

In the distillates, the normal presence of one component responsible for the authenticity and safety of the beverage - methyl alcohol - is usually found. Its formation is due to its precursor - pectin in the fruits. Pectin undergoes transformation due to the complex enzyme activity of the fruit pectolytic complex, which hydrolyzes it to methyl alcohol (Lukic et al., 2011; Coldea et al., 2011). The quantitative variation of methanol in grape distillates is in the range of $0.40-2.00 \mathrm{~g} / \mathrm{dm}^{3}$ (Velkov, 1996). Above these amounts, it can make the drink toxic and dangerous for consumption.

The aim of this study is to define the volatile composition of grape distillates with added extracts of Hypericum perforatym $\mathrm{L}$. 


\section{MATERIAL AND METHODS}

\section{Plant sources and extracts preparation}

The $50 \%$ and $70 \%$ ethanol extracts of St. John's wort (Hypericum perforatym L) were used as the plant source for incorporation into the distillate. This plant is from the family Hypericaceae. It is widespread in the fields, dry and light grassy places, from rarely wooded forests and glades, up to $1000 \mathrm{~m}$ above sea level, throughout Bulgaria (Landzhev, 2005).

The plant was harvested during the flowering period (May-September). The herb was collected from one place -Dalgata Barchina Locality, Dospat, Bulgaria. It was dried in shaded airy rooms at $22-25^{\circ} \mathrm{C}$. The dried parts were ground in an electric robot equipped with an electric grinder to obtain a finely ground substance from the dried herb. Six fractions with different particle diameters were obtained by determining the milled particle size of the dried St. John's wort (Hypericum perforatym L): Class I $\frac{132}{0} \mu \mathrm{m}-13,23 \%$; Class II $\frac{280}{132} \mu \mathrm{m}$ $23,43 \%$; Class III $\frac{450}{280} \mu \mathrm{m}-17,15 \%$; Class IV $\frac{670}{450} \mu \mathrm{m}-14,56 \%$; Class V $\frac{1000}{670} \mu \mathrm{m}-17,37 \%$; Class VI $\frac{2000}{1000} \mu \mathrm{m}-14,26 \%$; This diameters ensured good contact between the particles and the solvent during the extraction process. The ethanol extracts were prepared by pouring $1 \mathrm{~g}$ of the ground plant raw material with $20 \mathrm{ml}$ of $50 \%$ ethanol. The purity of the ethanol used was $95 \%$. The proportions of the amount of herb:solvent were calculated and the extraction was carried out to obtain the required amounts of extract for quantitative dosing to the experimental variants.

The extraction procedure was the same for the preparation of $70 \%$ ethanol extracts. The solvents $(50 \%$ and $70 \%$ ethanol solutions) added to the milled plan material stayed with the plant material at $18-20^{\circ} \mathrm{C}$ in the dark for 14 days. This is the period during which they were in contact for better extraction. Then they were filtered and the obtained pure extracts were stored at $0-4^{\circ} \mathrm{C}$.

The grapes for the variety Melnik-55 grown in the area of Polski Trambesh village, Sandanski municipality, Blagoevgrad region were used for the distillate preparation. $600 \mathrm{~kg}$ grapes was used from which 80 liters of distillate with $63 \%$ alcohol content have been obtained. The grapes were subjected to a fermentation process according to the classic scheme for the production of dry red wines: crushing and destemming, sulphitation $(50 \mathrm{mg} / \mathrm{kg} \mathrm{SO}$ ), inoculating with pure culture dry yeasts Saccharomyces cerevisiae - $20 \mathrm{~g} / \mathrm{hl}$, temperature of fermentation $-28^{\circ} \mathrm{C}$, separation from solids, further sulphitation, storage (Yankov, 1992). The distillation of the fermented material was carried out in a licensed distillery ("Denis-Marian Trenev 2008" Ltd, Novo Delchevo, Sandanski, Bulgaria). The experimental samples were prepared from the distillate obtained by adding of $50 \%$ and $70 \%$ ethanol extracts of St. John's wort (Hypericum perforatym $L$ ) in quantities of: $20,80,100,200,400$ and $600 \mathrm{ml}$. The beverages were poured up to one liter with distillate. Pure distillate without extracts was used as a control sample.

\section{Determination of alcohol content of obtained alcohol beverages}

The alcohol content of the obtained distillates was defined by specialized equipment with high precision - automatic distillation unit - DEE Distillation Unit with Densimat and Alcomat, Gibertini, Milan, Italy.

\section{Volatile content determination by GC-FID}

Gas chromatographic determination of the volatile components in distillates was done. The content of major volatile compounds was determined on the basis of stock standard solution prepared in accordance with the IS method 3752:2005 The method describes the preparation of standard solution with one congener (methanol) but the step of preparation was followed for the preparation of a solution with more compounds. The standard solution in this study included the compounds with purity $>99.0 \%$. The $2 \mu$ of prepared standard solution was injected in gas chromatograph Varian 3900 (Varian Analytical Instruments, Walnut Creek, California, USA) with a capillary column VF max MS (30 m, 0.25 $\mathrm{mm}$ ID, $\mathrm{DF}=0.25 \mu \mathrm{m}$ ), equipped with a flame ionization detector (FID). The used carrier gas was He. Hydrogen to support combustion was supplied to the chromatograph via a hydrogen bottle. The injection was manually by microsyringe.

The parameters of the gas chromatographic determination were: injector temperature $-220{ }^{\circ} \mathrm{C}$; detector temperature $-250{ }^{\circ} \mathrm{C}$, initial oven temperature $35{ }^{\circ} \mathrm{C} /$ retention $1 \mathrm{~min}$, rise to $55^{\circ} \mathrm{C}$ with step of $2{ }^{\circ} \mathrm{C} / \mathrm{min}$ for $11 \mathrm{~min}$, rise to 230 ${ }^{\circ} \mathrm{C}$ with step of $15^{\circ} \mathrm{C} / \mathrm{min}$ for $3 \mathrm{~min}$. Total time of chromatography analysis $25.67 \mathrm{~min}$. The identified retention times of the compounds in the standard solution were: acetaldehyde (3.141), ethyl acetate (3.758), methanol (3.871), 2 propanol (5.170), isopropyl acetate (5.975), 1-propanol (6.568), 2-butanol (7.731), propyl acetate (9.403), 2-methyl-propanol (10.970), 1-butanol (11.509), isobutyl acetate (11.662), ethyl butyrate (12.710), butyl acetate (12.752), 2 methyl-1-butanol (13.054), 4-methyl-2-pentanol (13.629), 3-methyl-1-butanol (13.840), 1-pentanol (15.180), isopenthyl acetate (15.965), pentyl acetate (16.033), 1-hexanol (16.276), ethyl hexanoate (16.376), hexyl acetate (16.510), 1-heptanol (16.596), linalool oxide (16.684), phenyl acetate (18.055), ethyl caprylate (18.625), $\alpha$-terpineol (19.066), 2-phenyl ethanol (19.369), nerol (19.694), $\beta$-citronellol (19.743), geraniol (19.831), ethyl decanoate (19.904). As an internal standard octanol was used.

After determination of the retention times of the compounds in the standard solution the identification and quantification of the volatile substances in the distillates was done. The volatile composition was determined based on direct injection of the distillates. Prepared samples were injected in an amount of $2 \mu 1$ in a gas chromatograph and was carried out an identification and quantification of the substances in each of them.

\section{Statistical processing}

Statistical analysis of the data was performed by determining the standard deviation ( \pm SD), with triplicate. It was made using Excel 2007 from the Microsoft Office Package (Microsoft Corporation, USA)

\section{RESULTS AND DISCUSSION}

The final concentration of ethyl alcohol in the distillates obtained was different with the different extracts used. In the control sample, it was 68.84 vol. \%. In the variants with the use of $50 \%$ alcohol extract of the used plant source, it moved in the range of 57.30 vol. $\%-67.48$ vol. $\%$. There was a proportional decrease in the alcoholic strength of each subsequent experimental variant. This was due to the substitution of a portion of the distillate with different amount of extract. The same tendency was observed when applying $70 \%$ ethanol extract of the plant The alcohol content of these experimental variants ranged from 67.14 vol. \% to 68.38 vol. $\%$

The identified and quantified volatile compounds in the control sample and distillates with $50 \%$ Hypericum perforatym L extract are shown in Table 1. Table 2 presents data for the volatile composition of the distillate obtained with the addition of $70 \%$ Hypericum perforatym $\mathrm{L}$ extract.

The total volatile composition included identified compounds of the groups of aldehydes, higher alcohols, esters, terpenes and methyl alcohol. The control sample shown a high total volatile composition $\left(1962.97 \pm 3.62 \mathrm{mg} / \mathrm{dm}^{3}\right)$. It represented the volatile composition of the pure distillate. The different ratios of the addition of Hypericum perforatym $\mathrm{L}$ extracts in the experimental samples led to a changed total volatile composition. In some samples it decreased, while in others it increased significantly in comparison with that found in the control. The highest total amount of volatile compounds for the samples with $50 \%$ ethanol extracts of the used plant was found in variant 1000:20 $\left(1911.35 \pm 4.92 \mathrm{mg} / \mathrm{dm}^{3}\right)$ This amount was lower than that found in the control sample. When $70 \%$ ethanol extract of Hypericum perforatym L was applied, a high amount of volatile compounds $\left(2240.06 \pm 2.29 \mathrm{mg} / \mathrm{dm}^{3}\right)$ was detected in a 1000:20 sample, significantly exceeding that of the control. A sample 1000:80 with $70 \%$ ethanol extract shown a slightly higher concentration of volatile compounds (1965.45 \pm $1.49 \mathrm{mg} / \mathrm{dm}^{3}$ ) than the control. Lower total concentrations of volatile compounds were found in the latter two variants 1000:400 $\left(503.26 \pm 0.78 \mathrm{mg} / \mathrm{dm}^{3}\right)$ and $1000: 600\left(259.49 \pm 0.30 \mathrm{mg} / \mathrm{dm}^{3}\right)$ with the addition of $50 \%$ ethanol extract, as well as in variants 1000:400 $\left(251.80 \pm 2.63 \mathrm{mg} / \mathrm{dm}^{3}\right)$ and 1000:600 (143.85 \pm $1.96 \mathrm{mg} / \mathrm{dm}^{3}$ ) of distillates with $70 \%$ ethanol extracts. This was due to the process of substitution of significant portions of the distillate with a higher amount of extract.

The total amount of volatile compounds in the experimental variants with the addition of $50 \%$ ethanol extract of Hypericum perforatym $\mathrm{L}$ ranged from 259.49 $\pm 0.30-1911.35 \pm 4.92 \mathrm{mg} / \mathrm{dm}^{3}$. When $70 \%$ ethanol extract was used, the range was $143.85 \pm 1.96-2240.06 \pm 2.29 \mathrm{mg} / \mathrm{dm}^{3}$.

The methanol was a constantly present component of distillates. In the distillates analyzed, with the addition of $50 \%$ ethanol extract of Hypericum perforatym $\mathrm{L}$ it ranged from $58.69 \pm 0.08$ to $316.15 \pm 0.18 \mathrm{mg} / \mathrm{dm}^{3}$. In the control sample, it was found to be highest $\left(364.74 \pm 0.32 \mathrm{mg} / \mathrm{dm}^{3}\right)$. In the samples with the addition of $50 \%$ ethanol extract, a proportional decrease in methanol content was observed in the process of increasing the amount of added extract. A similar trend was observed with the application of $70 \%$ ethanol extract of the herb. The substitution of parts of the distillate with ethanol extracts $(50 \%$ and $70 \%)$ of Hypericum perforatym $\mathrm{L}$ resulted in a reduction of the levels of methyl alcohol in the final distillate. And although all established methanol levels in the samples were within its tolerable level, a reduction in methanol levels was reported when extracts were incorporated, which contributed to the decreased methanol content of the distillate. The data obtained on total methanol concentration were correlated with those reported by Velkov, 1996.

The aldehyde fraction was represented by its major component, acetaldehyde. In the control sample, it was found to be $54.72 \pm 0.25 \mathrm{mg} / \mathrm{dm}^{3}$. A reduction in its content in the experimental samples was observed compared to the control for reasons similar to the methanol reduction (replacement of certain quantities of distillate with Hypericum perforatym $\mathrm{L}$ extract). This compound was found in amounts ranging from $0.05 \pm 0.01-78.58 \pm 0.14 \mathrm{mg} / \mathrm{dm}^{3}$ when applying $50 \%$ ethanol extracts and $0.05 \pm 0.01-46.15 \pm 0.12 \mathrm{mg} / \mathrm{dm}^{3}$ when applying $70 \%$ ethanol extracts. Its amounts were lower in distillate with $70 \%$ ethanol extracts of Hypericum perforatym L. All acetaldehyde concentrations found in the present 
study were normal for distillates, but at high amounts this compound imparts an unpleasant acuity to the aroma and taste of the distillate (Velkov, 1996). The incorporation of the extracts resulted in a reduction that reduced or almost completely eliminated the aromatic disadvantages of the acetaldehyde.

Table 1 Identified volatile compounds in the control (distillate) and experimental samples with added $50 \%$ ethanol extract of Hypericum perforatym L in different amounts

\begin{tabular}{|c|c|c|c|c|c|c|c|}
\hline \multirow{2}{*}{$\begin{array}{l}\text { IDENTIFIED } \\
\text { COMPOUNDS, } \\
\mathrm{mg} / \mathrm{dm}^{3}\end{array}$} & \multicolumn{7}{|c|}{ DISTILLATES WITH ADDED ETHANOL EXTRACT (50\%) FROM Hypericum perforatym L } \\
\hline & CONTROL & 1000:20 & 1000:80 & 1000:100 & 1000:200 & 1000:400 & 1000:600 \\
\hline Ethyl alcohol, vol.\% & 68.84 & 67.78 & 66.22 & 66.22 & 64.86 & 60.60 & 57.30 \\
\hline Acetaldehyde & $54.72 \pm 0.25$ & $78.58 \pm 0.14$ & $44.95 \pm 0.07$ & $31.96 \pm 0.12$ & $35.15 \pm 0.04$ & $17.26 \pm 0.02$ & $0.05 \pm 0.01$ \\
\hline Methanol & $364.74 \pm 0.32$ & $316.15 \pm 0.18$ & $219.72 \pm 0.21$ & $182.29 \pm 0.10$ & $252.24 \pm 1.00$ & $97.11 \pm 0.08$ & $58.69 \pm 0.08$ \\
\hline 2-methyl-1-butanol & $190.38 \pm 0.12$ & $187.99 \pm 0.09$ & $128.07 \pm 0.17$ & $94.46 \pm 0.15$ & $127.11 \pm 0.17$ & $48.37 \pm 0.06$ & $22.98 \pm 0.04$ \\
\hline 3-methyl-1-butanol & $831.95 \pm 0.15$ & $807.17 \pm 2.12$ & $584.38 \pm 0.26$ & $431.49 \pm 0.98$ & $561.76 \pm 0.21$ & $217.82 \pm 0.23$ & $109.05 \pm 0.12$ \\
\hline 4-methyl-2-pentanol & ND & ND & ND & ND & $0.05 \pm 0.01$ & $0.05 \pm 0.01$ & ND \\
\hline 1-propanol & $33.89 \pm 0.56$ & $31.32 \pm 0.04$ & $23.04 \pm 0.06$ & $18.94 \pm 0.08$ & $24.34 \pm 0.05$ & $8.54 \pm 0.06$ & $0.05 \pm 0.01$ \\
\hline 2-propanol & $\mathrm{ND}$ & $0.05 \pm 0.01$ & $0.05 \pm 0.01$ & $0.05 \pm 0.01$ & $0.05 \pm 0.01$ & $0.05 \pm 0.01$ & $0.05 \pm 0.01$ \\
\hline 2-butanol & $\mathrm{ND}$ & $246.50 \pm 1.17$ & $172.93 \pm 0.17$ & $131.47 \pm 0.11$ & $180.22 \pm 0.12$ & $63.41 \pm 0.12$ & $36.96 \pm 0.03$ \\
\hline 2-methyl-1-propanol & $245.01 \pm 1.05$ & $0.05 \pm 0.01$ & $\mathrm{ND}$ & $\mathrm{ND}$ & $0.05 \pm 0.01$ & $0.05 \pm 0.01$ & $0.05 \pm 0.01$ \\
\hline 1-pentanol & $0.05 \pm 0.01$ & $0.05 \pm 0.01$ & ND & ND & ND & ND & ND \\
\hline 1-hexanol & ND & ND & ND & $0.05 \pm 0.01$ & ND & ND & ND \\
\hline 2-phenylethanol & ND & $0.05 \pm 0.01$ & ND & ND & ND & $0.05 \pm 0.01$ & ND \\
\hline $\begin{array}{l}\text { Total higher and aromatic } \\
\text { alcohols }\end{array}$ & $1301.28 \pm 1.89$ & $1273.18 \pm 3.46$ & $908.47 \pm 0.67$ & $676.46 \pm 1.34$ & $893.58 \pm 0.58$ & $338.34 \pm 0.51$ & $169.14 \pm 0.22$ \\
\hline Ethyl acetate & $242.08 \pm 1.12$ & $199.38 \pm 0.98$ & $140.84 \pm 0.19$ & $109.74 \pm 0.21$ & $148.87 \pm 0.15$ & $50.25 \pm 0.11$ & $31.41 \pm 0.04$ \\
\hline Propyl acetate & ND & ND & $0.05 \pm 0.01$ & $0.05 \pm 0.01$ & ND & ND & ND \\
\hline Isopropyl acetate & ND & $0.05 \pm 0.01$ & $0.05 \pm 0.01$ & ND & ND & ND & ND \\
\hline Ethyl butyrate & ND & $0.05 \pm 0.01$ & $0.05 \pm 0.01$ & $0.05 \pm 0.01$ & $0.05 \pm 0.01$ & $0.05 \pm 0.01$ & ND \\
\hline Ethyl caprylate & $0.05 \pm 0.02$ & $0.05 \pm 0.01$ & $0.05 \pm 0.01$ & ND & ND & $0.05 \pm 0.01$ & ND \\
\hline Phenyl acetate & ND & $0.05 \pm 0.01$ & $0.05 \pm 0.01$ & $0.05 \pm 0.01$ & ND & $0.05 \pm 0.01$ & $0.05 \pm 0.01$ \\
\hline Ethyl decanoate & $0.05 \pm 0.01$ & $43.71 \pm 0.08$ & $88.20 \pm 0.19$ & $\mathrm{ND}$ & ND & $\mathrm{ND}$ & $\mathrm{ND}$ \\
\hline Total esters & $242.18 \pm 1.15$ & $243.29 \pm 1.1$ & $229.29 \pm 0.43$ & $109.89 \pm 0.24$ & $148.92 \pm 0.16$ & $50.40 \pm 0.14$ & $31.46 \pm 0.05$ \\
\hline$\alpha-$ terpineol & ND & $0.05 \pm 0.02$ & ND & $0.05 \pm 0.01$ & ND & $0.05 \pm 0.01$ & $0.05 \pm 0.01$ \\
\hline Nerol & ND & $0.05 \pm 0.01$ & $0.05 \pm 0.01$ & ND & ND & ND & $0.05 \pm 0.01$ \\
\hline$\beta-$ citronellol & ND & ND & $0.05 \pm 0.01$ & $0.05 \pm 0.01$ & $0.05 \pm 0.01$ & $0.05 \pm 0.01$ & ND \\
\hline Geraniol & $0.05 \pm 0.01$ & $0.05 \pm 0.01$ & $0.05 \pm 0.01$ & $0.05 \pm 0.01$ & $0.05 \pm 0.01$ & $0.05 \pm 0.01$ & $0.05 \pm 0.01$ \\
\hline Total terpenes & $0.05 \pm 0.01$ & $0.15 \pm 0.04$ & $0.15 \pm 0.03$ & $0.15 \pm 0.03$ & $0.10 \pm 0.02$ & $0.15 \pm 0.03$ & $0.15 \pm 0.03$ \\
\hline TOTAL CONTENT & $1962.97 \pm 3.62$ & $1911.35 \pm 4.92$ & $1402.58 \pm 1.41$ & $1000.75 \pm 1.83$ & $1329.99 \pm 1.8$ & $503.26 \pm 0.78$ & $259.49 \pm 0.39$ \\
\hline
\end{tabular}

The higher alcohols are a fermentation products of the metabolism of the yeast microflora. In the control sample, their total detected amount was $1301.28 \pm 1.89$ $\mathrm{mg} / \mathrm{dm}^{3}$. In the experimental samples with $50 \%$ ethanol extract of Hypericum perforatym $\mathrm{L}$ the amount of higher alcohols was lower than that found in the control. The same trend was observed in the samples with $70 \%$ ethanol extract. All experimental samples shown lower values for this indicator.

The higher alcohols identified as mainly present in all samples included 2methyl-1-butanol, 3-methyl-1-butanol, 1-propanol and 2-butanol.

\begin{tabular}{|c|c|c|c|c|c|c|}
\hline \multirow[t]{2}{*}{$\begin{array}{l}\text { IDENTIFIED COMPOUNDS, } \\
\mathrm{mg} / \mathrm{dm}^{3}\end{array}$} & \multicolumn{6}{|c|}{ DISTILLATES WITH ADDED ETHANOL EXTRACT (70\%) FROM Hypericum perforatym L } \\
\hline & 1000:20 & 1000:80 & 1000:100 & 1000:200 & $1000: 400$ & 1000:600 \\
\hline Ethyl alcohol, vol.\% & 68.18 & 68.04 & 68.38 & 67.44 & 66.84 & 67.14 \\
\hline Acetaldehyde & $45.71 \pm 0.21$ & $46.15 \pm 0.12$ & $42.17 \pm 0.12$ & $0.05 \pm 0.01$ & $8.00 \pm 0.23$ & $6.23 \pm 0.18$ \\
\hline Methanol & $294.65 \pm 0.15$ & $338.92 \pm 0.26$ & $269.54 \pm 0.16$ & $54.01 \pm 0.38$ & $44.17 \pm 0.28$ & $25.68 \pm 0.72$ \\
\hline 2-methyl-1-butanol & $221.20 \pm 0.14$ & $190.84 \pm 0.22$ & $136.40 \pm 0.17$ & $35.56 \pm 0.48$ & $23.21 \pm 0.56$ & $12.60 \pm 0.83$ \\
\hline 3-methyl-1-butanol & $953.33 \pm 1.21$ & $880.33 \pm 0.36$ & $615.60 \pm 0.38$ & $161.58 \pm 0.59$ & $108.86 \pm 0.72$ & $59.53 \pm 0.94$ \\
\hline 4-methyl-2-pentanol & $0.05 \pm 0.01$ & $0.05 \pm 0.01$ & ND & ND & ND & $0.05 \pm 0.01$ \\
\hline 1-propanol & $35.89 \pm 0.05$ & $32.23 \pm 0.08$ & $25.14 \pm 0.34$ & $5.20 \pm 0.60$ & $4.33 \pm 0.18$ & $2.35 \pm 0.09$ \\
\hline 2-propanol & $0.05 \pm 0.01$ & $0.05 \pm 0.01$ & $0.05 \pm 0.01$ & $0.05 \pm 0.01$ & $0.05 \pm 0.01$ & $0.05 \pm 0.01$ \\
\hline 2-butanol & $266.32 \pm 0.18$ & $259.65 \pm 0.09$ & $192.71 \pm 0.42$ & $11.34 \pm 0.19$ & $34.33 \pm 0.21$ & $18.10 \pm 0.14$ \\
\hline 2-methyl-1-propanol & $0.05 \pm 0.01$ & $0.05 \pm 0.01$ & ND & $0.05 \pm 0.01$ & ND & ND \\
\hline 1-hexanol & $0.05 \pm 0.01$ & ND & $\mathrm{ND}$ & ND & ND & ND \\
\hline 2-phenylethanol & $0.05 \pm 0.01$ & $0.05 \pm 0.01$ & ND & ND & ND & $3.92 \pm 0.30$ \\
\hline $\begin{array}{l}\text { Total higher and aromatic } \\
\text { alcohols }\end{array}$ & $1476.99 \pm 1.63$ & $1363.25 \pm 0.79$ & $969.90 \pm 1.32$ & $213.78 \pm 1.88$ & $170.78 \pm 1.68$ & $96.60 \pm 0.45$ \\
\hline Ethyl acetate & $394.08 \pm 0.19$ & $216.93 \pm 0.28$ & $182.69 \pm 0.46$ & $24.62 \pm 0.59$ & $28.45 \pm 0.36$ & $14.94 \pm 0.53$ \\
\hline Propyl acetate & ND & $\mathrm{ND}$ & $0.05 \pm 0.01$ & $\mathrm{ND}$ & $0.05 \pm 0.01$ & $0.05 \pm 0.01$ \\
\hline Isopropyl acetate & $0.05 \pm 0.01$ & ND & ND & $36.08 \pm 0.78$ & $0.05 \pm 0.01$ & ND \\
\hline Ethyl butyrate & ND & $0.05 \pm 0.01$ & $0.05 \pm 0.01$ & $\mathrm{ND}$ & $0.05 \pm 0.01$ & $0.05 \pm 0.01$ \\
\hline Ethyl caprylate & ND & ND & ND & ND & $0.05 \pm 0.01$ & $0.05 \pm 0.01$ \\
\hline Ethyl hexanoate & ND & ND & ND & ND & ND & ND \\
\hline Hexyl acetate & ND & ND & $\mathrm{ND}$ & $\mathrm{ND}$ & $0.05 \pm 0.01$ & ND \\
\hline Phenyl acetate & $7.69 \pm 0.03$ & $0.05 \pm 0.01$ & ND & ND & ND & $0.05 \pm 0.01$ \\
\hline Ethyl decanoate & $20.79 \pm 0.05$ & $0.05 \pm 0.01$ & $0.05 \pm 0.01$ & $\mathrm{ND}$ & $0.05 \pm 0.01$ & $0.05 \pm 0.01$ \\
\hline Total esters & $422.61 \pm 0.28$ & $217.08 \pm 0.31$ & $182.84 \pm 0.49$ & $60.70 \pm 1.37$ & $28.75 \pm 0.42$ & $15.19 \pm 0.58$ \\
\hline$\alpha-$ terpineol & $\mathrm{ND}$ & ND & ND & ND & ND & $0.05 \pm 0.01$ \\
\hline Nerol & $0.05 \pm 0.01$ & ND & $0.05 \pm 0.01$ & ND & ND & $0.05 \pm 0.01$ \\
\hline$\beta$ - citronellol & ND & $0.05 \pm 0.01$ & ND & ND & $0.05 \pm 0.01$ & ND \\
\hline Geraniol & $0.05 \pm 0.01$ & ND & $0.05 \pm 0.01$ & ND & $0.05 \pm 0.01$ & $0.05 \pm 0.01$ \\
\hline Total terpenes & $0.10 \pm 0.02$ & $0.05 \pm 0.01$ & $0.10 \pm 0.02$ & - & $0.10 \pm 0.02$ & $0.15 \pm 0.03$ \\
\hline TOTAL CONTENT & $2240.06 \pm 2.29$ & $1965.45 \pm 1.49$ & $1464.55 \pm 2.11$ & $328.54 \pm 3.64$ & $251.80 \pm 2.63$ & $143.85 \pm 1.96$ \\
\hline
\end{tabular}


3-methyl-1-butanol was the alcohol found in the highest amounts of the higher alcohols fraction. Its concentration in the control sample was $831.95 \pm 0.15$ $\mathrm{mg} / \mathrm{dm}^{3}$. The experimental samples obtained with the addition of $50 \%$ ethano extract of Hypericum perforatym $\mathrm{L}$ shown a concentration of 3-methyl-1-butano lower than the control. There has been a proportional gradual decrease in its content when the content of the added extract was increased. With the application of $70 \%$ ethanol extracts, the highest content of 3-methyl-1-butanol $(953.33 \pm 1.21$ $\mathrm{mg} / \mathrm{dm}^{3}$ ) was detected in the 1000:20 sample. Its quantities were reduced proportionally in each subsequent experimental sample. This compound is a major component of the higher alcohols group. It imparts the aroma of malt and whiskey (Francis and Newton, 2008).

2-methyl-1-butanol was found in the control sample at $190.38 \pm 0.12 \mathrm{mg} / \mathrm{dm}^{3}$. In all other samples in the distillates with added $50 \%$ ethanol extracts of the herb, its content was lower than the control. The amount of this compound in the samples with $70 \%$ ethanol extract was reduced in the direction of control to experimenta variants. It should be noted that with applied $70 \%$ ethanol extracts the amounts of 2-methyl-1-butanol were lower in comparison with the variants in which the 50\% ethanol extract of the plant was applied.

1-propanol was identified in all beverages studied. This compound is normally present in distillates. Its concentration ranging from $140.00 \mathrm{mg} / \mathrm{dm}^{3}$ to 240.00 $\mathrm{mg} / \mathrm{dm}^{3}$ (Velkov, 1996). In the control sample, it was identified in an amount of $33.89 \pm 0.56 \mathrm{mg} / \mathrm{dm}^{3}$. The incorporation of both types of extracts $(50 \%$ and $70 \%)$ resulted in a proportional decrease in the concentration of 1-propanol in the experimental variants.

Other important higher alcohols - 2-propanol, 2-methyl-1-propanol, pentanol and hexanol were identified in smaller quantities in the samples. One aromatic alcohol (2-phenylethanol) has also been identified.

The esters are with fundamental contribution to the aromatic quality of the alcoholic beverages. They have a low threshold of aromatic perception and impart different aromatic nuances (Chobanova, 2012). Considering the tota ester content in the distillates with the applied $50 \%$ extract of the herb, one variant was distinguished - 1000:20. It shown slightly higher total ester conten $\left(257.11 \pm 0.33 \mathrm{mg} / \mathrm{dm}^{3}\right)$, compared to that found in the control $(242.18 \pm 1.15$ $\left.\mathrm{mg} / \mathrm{dm}^{3}\right)$. This supported to the intensified ester flavor of these one experimenta distillate. When the 70\% ethanol extract was applied, variant 1000:20 shown twice higher concentration of esters $\left(422.61 \pm 0.28 \mathrm{mg} / \mathrm{dm}^{3}\right)$ compared to the control.

The major representative of the ester fraction was ethyl acetate. The compound is double-acting. When it is in normal concentrations $\left(\max .400 .00 \mathrm{mg} / \mathrm{dm}^{3}\right.$ ), it harmonizes the fruity aroma of the distillate, at higher concentrations it gives an unpleasant acetic acid taste (Velkov, 1996). When 50\% ethanol extract was used, ethyl acetate was found to have the highest concentration $\left(242.08 \pm 1.12 \mathrm{mg} / \mathrm{dm}^{3}\right)$ in the control sample. In the experimental variants, its concentration decreased regularly $\left(199.38 \pm 0.98 \mathrm{mg} / \mathrm{dm}^{3}-31.41 \pm 0.04 \mathrm{mg} / \mathrm{dm}^{3}\right)$. When $70 \%$ ethano extract of Hypericum perforatym $\mathrm{L}$ was used, ethyl acetate was found in very high amounts $\left(394.08 \pm 0.19 \mathrm{mg} / \mathrm{dm}^{3}\right)$ in experimental variant 1000:20. Its effect in this sample was negative because its concentration was very close to the threshold of negative sensory influence. In the remaining samples it decreased regularly $\left(216.93 \pm 0.28 \mathrm{mg} / \mathrm{dm}^{3}-14.94 \pm 0.53 \mathrm{mg} / \mathrm{dm}^{3}\right)$

The results found for the concentration of ethyl acetate indicated that the incorporation of Hypericum perforatym $\mathrm{L}$ extracts may serve as a strategy to reduce and eliminate the negative effect of the higher accumulations of this ester in the distillates. The remaining esters were identified in smaller quantities. The slightly higher concentrations of phenyl acetate $\left(7.69 \pm 0.03 \mathrm{mg} / \mathrm{dm}^{3}\right)$ and ethyl decanoate $\left(20.79 \pm 0.05 \mathrm{mg} / \mathrm{dm}^{3}\right)$ in the $1000: 20$ variant were established by the use of $70 \%$ ethanol extract of Hypericum perforatym $\mathrm{L}$.

Propyl acetate, isopropyl acetate, ethyl butyrate, ethyl caprylate and ethyl hexanoate were identified in different amounts in the samples.

Only one terpene - geraniol $\left(0.05 \pm 0.01 \mathrm{mg} / \mathrm{dm}^{3}\right)$ was identified in the control sample, which determined the lowest total terpenic content of this sample. The amounts of the terpenes found in the experimental samples were higher.

The terpenes are products of the vine plant, from which they pass into the grapes and from there into their products (Peinado et al., 2004). The higher tota concentration of terpenes in all experimental variants was due to the incorporation of terpenic compounds from the Hypericum perforatym $\mathrm{L}$ extracts into the experimental distillates obtained. Four terpenes have been identified - $\alpha$ terpineol, $\beta$-citronellol, nerol and geraniol. Extensive studies have confirmed the presence of biological and pharmacological activities of these compounds, mainly related to their high antioxidant activity (Gonzalez-Burgoz and GomesSeramilos, 2012). The incorporation of Hypericum perforatym $\mathrm{L}$ extracts to the distillates resulted in an increased final concentration of common terpenes in the beverage, which can intensify its biological effect.

The potential application of the obtained distillates with added Hypericum perforatym L.extracts can be related to the production of new alcoholic beverages with added medicinal herb extracts. The distillates obtained can be adjusted to the prescribed alcoholic strength for a particular group of higher alcoholic beverages (eg. brandy up to 41 vol. \% ethanol content)

\section{CONCLUSION}

The following conclusions can be drawn from this study:

- Of all experimental samples studied, the variants 1000:20 with the application of $70 \%$ ethanol extract shown the highest total volatile content $(2240.06 \pm 2.29$ $\left.\mathrm{mg} / \mathrm{dm}^{3}\right)$, significantly exceeding that of the control variant $(1962.97 \pm 3.62$ $\left.\mathrm{mg} / \mathrm{dm}^{3}\right)$.

- The incorporation of Hypericum perforatym L extracts, which replace part of the distillate, resulted in a reduction of the methyl alcohol content of the experimental samples.

- The use of extracts resulted in the reduction of acetaldehyde levels from the control sample to the experimental variants. This reduced the aromatic disadvantage of the higher concentrations of acetaldehyde.

-A diverse composition of higher alcohols has been identified. Four highe alcohols were practically found in all variants studied: 3-methyl-1-butanol, 2 methyl-1-butanol, 2-butanol and 1-propanol. In smaller amounts, 2-propanol, 2 methyl-1-propanol, pentanol and hexanol were found. One aromatic alcohol, 2 phenylethanol, has also been identified.

- The incorporation of 50\% ethanol extract of Hypericum perforatym $\mathrm{L}$ in variant 1000:20 resulted in a slight increase in total ester content $(243.29 \pm 1.10)$ compared to the control $\left(242.18 \pm 1.15 \mathrm{mg} / \mathrm{dm}^{3}\right)$. When $70 \%$ ethanol extract was applied in variant 1000:20, twice as much esters $\left(422.61 \pm 0.28 \mathrm{mg} / \mathrm{dm}^{3}\right)$ were accumulated compared to the control.

- The reduction of the levels of the basic ester - ethyl acetate in the direction of control to each subsequent experimental variant can serve as a strategy to reduce or eliminate the negative effect of the higher accumulations of this ester.

- The incorporation of ethanol extracts $(50 \%$ and $70 \%)$ of Hypericum perforatym $\mathrm{L}$ has been shown to increase the total terpenic content. In almost all experimental samples a higher total terpenic content was found compared to the control due to the terpenic composition of the herb itself.

- The produced distillates with added extracts of Hypericum perforatym $\mathrm{L}$ can be used for obtaining of new higher alcoholic beverages with added medicinal herb extracts.

\section{REFERENCES}

CHOBANOVA, D. 2012. Enology. Part I: Composition of wine. Academic Press of University of Food Technologies, Plovdiv, Bulgaria. (BG)

COLDEA, T., SOCACIN, C., DAN VADNAR, M. 2011. Gas-chromatographic analysis of major volatile compounds found in traditional fruit brandies from Transylvania, Romania. Not. Bot. Horti. Agrobo., 39(2): 109-116. https://doi.org/10.15835/nbha3926053

COLDEA, T., SOCACIN, C., TOFANĂ, M., VÉKONY, E., RANTA, N. 2012 Impact of Distillation Process on the Major Volatile Compounds as Determined by GC-FID Analysis in Apple Brandy Originated from Transylvania, Romania Bulletin UASVM Agriculture, 69(2): 228 - 235.

FRANCIS, I., NEWTON, J. 2008. Determining wine aroma from compositional data. Australian Journal of Grape and Wine Research, 11(2): 114-126. DOI: 10.1111/j.1755-0238.2005.tb00283.x

GONZALEZ-BURGOS, E., GOMEZ-SERRAMILLOS, MP. 2012. Terpene compounds in nature: a rewivew of their potential antioxidant activity. Current medicinal chemistry, 19(31): 5319-5341. https://doi.org/10.2174/092986712803833335

GREIZERSTEIN, H.B. 1981. Congener contents of alcoholic beverages. Journal of Studies on Alcohol, 42(11): $1030 \quad-1037$. https://doi.org/10.15288/jsa.1981.42.1030

INDIAN STANDARD 3752:2005. Alcohol Drinks - Methods of Test (Second Revision)

IVANOV, I., VRANCHECA, Z., MARCHEV, A., PETKOVA, N., ANEVA, I. DENEV, P., GEORGIEV, V., PAVLOV, A. 2014. Antioxidant activities and phenolic compounds I Bulgarian Fumaria species. International Journal of Current Microbiology Applied Science, 3(2): 296-306.

KOSTIK, V., GJORGESKA, B., ANGELOVSKA, B., KOVACHEVSKA, I. 2014. Determination of some volatile compounds in fruit spirits produced from grapes (Vitis vinifera L.) and plums (Prunus domestica L.) cultivars. Science Journal of Analytical Chemistry, 2(4): 41-46. https://doi.org/10.11648/j.sjac.20140204.12

LANDZHEV, I. 2005. Encyclopedia of Medicinal Plants in Bulgaria, Herbs, Diseases. Editor "Trud", 122 - 123 (BG).

LENGYEL, E. 2012. Primary aromatic character of wines. Acta Universitatis Cibiniensis Series E: FOOD TECHNOLOGY, XVI (1): 3-18.

LUAN, F., MOSANDL, A., GUBESCH, M., MATTHIAS, M., WÜST, M. 2006. Enantioselective analysis of monoterpenes in different grape varieties during berry ripening using stir bar sorptive extraction and solid phase extractionenantioselective-multidimensional gas chromatography-mass spectrometry. Journal of Chromatography A, 1112: 369-374. https://doi.org/10.1016/i.chroma.2005.12.056

LUKIC, I., MILICEVIC, B., BANOVIC, M., TOMAS, S., RADEKA, S. PERSURIC, D. 2011. Secondary aroma compounds in fresh grape marc brandies 
as a result of variety and corresponding production technology. Food Technology Biotechnology, 49(2): 277-293.

MARINOV, M. 2005. Technology of alcoholic beverages and spirits. Plovdiv, Bulgaria. Academic Publishing of University of Food Technologies. ISSN 0477 0250. (BG)

MARKU, K., KONGOLI, R., MARA, V. 2015. Influence of the Distillation Process on the Aromatic Compounds of the Distillate Produced by "Muschat Hamburg" Cultivated in Durres. International Journal of Advanced Research in Science, Engineering and Technology, 2(5): 617-621.

PEINADO, A., MORENO, J., BUENO, I., MORENO, A., MAURICIO, C. 2004 Comparative study of aromatic compounds in two young white wines subjected to pre-fermentative cryomaceration. Food Chemistry, 84: 585-590. https://doi.org/10.1016/s0308-8146(03)00282-6

PETKOVA, N., IVANOV, I., DENEV, P., PAVLOV, A. 2014. Bioactive substance and free radical scavenging activities of flour from Jerusalem Artichoke (Helianthus tuberosus L.) tubers - a comparative study. Turkish Journal of Agricultured and Natural Sciences, 2: 1773-1778.

STOILOVA, I., KRASTANOV, A., STOYANOVA, A., DENEV, P., GARGOVA, S. 2007. Antioxidant activity of ginger extract (Zingiber officinale) Food Chemistry, 102(3): 764-770. https://doi.org/10.1016/j.foodchem.2006.06.023

TEŠEVIĆ, V, NIKIĆEVIĆ, N, MILOSAVLJEVIĆ, S, BAJIĆ, D, VAJS, V VUČKOVIĆ, I, VUJISIĆ, L, ĐORDEVIĆ, I, STANKOVIĆ, M, VELIČKOVIĆ, M. 2009. Characterization of volatile compounds of "Drenja", an alcoholic beverage obtained from the fruits of cornelian cherry. Journal of Serbian Chemical Society, 74(2): 117-128. https://doi.org/10.2298/jsc0902117t

VELKOV, E. 1996. Encyclopedia of alcoholic beverages. "Poligrafia" Ltd., Plovdiv, Bulgaria, 1996, ISBN 954-698-002-1 (BG).

YANKOV, A., KUKUNOV, S., YANKOVA, T. 2000. Technology of wine and higher alcohol drinks. Publisher: Teodoros, Sofia, Bulgaria, p: 193 (BG).

YANKOV, A. 1992. Winemaking Technology. Sofia, Zemizdat, (1992), 355 pp. (BG). 